\title{
Review: Penerapan Metode Single-Minute Exchange of Dies Sebagai Upaya Peningkatan Produktivitas Kerja Di Industri Farmasi
}

\author{
Dian Amalia Maharani ${ }^{*, 1}$, Ida Musfiroh² \\ ${ }^{1}$ Program Studi Profesi Apoteker, Fakultas Farmasi, Universitas Padjadjaran \\ ${ }^{2}$ Departemen Analisis Farmasi dan Kimia Medisinal \\ Jalan Raya Bandung-Sumedang KM 21, Sumedang 45363 \\ *Email: dian16013@mail.unpad.ac.id \\ (Submit 29/7/2021, Revisi 10/8/2021, Diterima 18/8/2021, Terbit 22/8/2021)
}

\begin{abstract}
Abstrak
Seiring dengan perkembangan industri farmasi yang semakin pesat, suatu industri farmasi harus dapat menciptakan proses produksi yang efektif dan efisien agar proses penghantaran produk ke konsumen berjalan dengan baik. Namun, keterlambatan dalam proses produksi menjadi permasalahan utama yang dihadapi industri farmasi saat ini yang menyebabkan terlambatnya proses penghantaran produk ke konsumen. Hal tersebut dapat meyebabkan menurunnya daya saing industri farmasi di tengah pasar farmasi yang semakin kompetitif. Salah satu cara untuk mengurangi keterlambatan proses produksi dilakukan dengan menerapkan Lean Manufacturing System (LMS) menggunakan metode Single Minute of Exchange Die (SMED). Metode SMED ini dapat di implementasi dengan memisahkan antara waktu persiapan/pergantian internal menjadi eksternal. Artikel review ini bertujuan untuk memberikan gambaran tentang penerapan metode SMED yang dapat mengurangi pemborosan sehingga dapat meningkatkan produktivitas kerja di industri farmasi. Metode yang digunakan dalam review artikel ini ialah dengan penelurusan literatur secara online yang diakses dari situs Google Scholar dan ScienceDirect dengan kata kunci "Penerapan Metode Single Minute of Exchange Die (SMED) di industri" dan "Lean Manufacturing System (LMS)". Hasil yang diperoleh berdasarkan review yaitu penerapan metode SMED di industri farmasi dapat menurunkan waktu persiapan/pergantian dalam proses produksi yang dilihat dari perbandingan antara waktu sebelum dan sesudah perbaikan. Penerapan metode SMED dalam proses produksi dapat menurunkan waktu persiapan/pergantian secara signifikan dengan presentase sebesar 39,97\%. Oleh karena itu, dapat disimpulkan bahwa metode SMED dapat diterapkan di industri farmasi untuk meningkatkan produktivitas kerja industri farmasi.
\end{abstract}

Kata kunci: Industri farmasi, Lean Manufacturing System, setup, changeover, SMED. 


\section{Pendahuluan}

Perkembangan industri farmasi yang semakin pesat pada saat ini maka dibutuhkan suatu kemampuan industri dalam menciptakan proses yang efektif dan efisien dalam melakukan serangkaian proses. Adapun tujuan utama dari industri yaitu mencapai keuntungan maksimal. ${ }^{1}$ Industri yang dapat bersaing harus mampu memuaskan konsumen dengan menyediakan pelayanan produk yang lebih cepat dan berkualitas yang memiliki keunggulan dibanding pesaing. ${ }^{2}$ Peningkatan kinerja yang lebih cepat dan berkualitas ini membutuhkan suatu proses perbaikan untuk memenuhi permintaan konsumen. ${ }^{3}$ Industri seringkali merasakan terjadinya pemborosan (waste) pada suatu proses kinerja tetapi industri tidak dapat mengevaluasi atau melakukan pengukuran. Padahal pemborosan dapat berpotensi mengurangi produktivitas industri. Pemborosan dapat disebabkan tingginya total waktu henti (downtime) dalam pelaksanaan produksi. Tingginya total waktu henti dalam suatu proses dapat menggangu kelancaran dari operasi industri tersebut. Oleh karena itu, suatu proses harus semaksimal mungkin dapat selesai dengan waktu yang telah ditentukan dengan dilakukan penentuan urutan kegiatan dan waktu penyelesaian kegiatan tersebut. Hal tersebut dilakukan karena keterlambatan suatu proses dapat mengakibatkan pertambahan waktu sehingga akan menambah biaya. ${ }^{4,5}$ Kondisi tersebut dapat menyebabkan industri mengalami kesulitan dalam mencapai produktivitas yang baik. ${ }^{6}$ Faktor yang mempengaruhi produktivitas industri diantaranya waktu persiapan (setup) atau pergantian (changeover), proses dan kondisi mesin. Dimana waktu persiapan/waktu pergantian dan waktu proses sangat mempengaruhi waktu siklus pembuatan suatu produk. ${ }^{7}$

Salah satu sistem yang dapat membantu memenuhi permintaan konsumen dengan efektif dan efisien yaitu Lean Manufacturing System (LMS). Lean Manufacturing System (LMS) menawarkan upaya untuk menciptakan budaya berkelanjutan dalam perbaikan proses dengan menghilangkan permborosan dan meningkatkan nilai tambah. ${ }^{3}$ Adapun pendekatan yang dapat diupayakan dalam mereduksi waktu persiapan/waktu pergantian dalam produksi pada LSM untuk meningkatkan kinerja operator yaitu dengan menggunakan metode Single Minute of Exchange Die (SMED). Metode SMED merupakan salah satu alat persiapan/pergantian dalam mengurangi pemborosan dengan memisahkan antara internal waktu persiapan/pergantian dan eksternal waktu persiapan/pergantian. Perubahan yang dapat dirasakan dalam menurunkan waktu pemborosan dalam menggunakan metode ini dengan membandingkan selisih antara waktu sebelum menggunakan metode SMED dengan waktu setelah menggunakan metode SMED dalam aktivitas produksi. Oleh karena itu, artikel ini dibuat untuk memberikan gambaran tentang penerapan metode SMED yang dapat mengurangi pemborosan sehingga dapat meningkatkan produktivitas kerja di industri farmasi. 8 Selain itu, dalam review artikel ini akan dibahas secara singkat mengenai LMS, SMED, dan beberapa penerapan metode SMED dalam menurunkan waktu persiapan/pergantian proses produksi di berbagai industri. 


\section{Metode}

Penyusunan review artikel ini dilakukan dengan penelusuran literatur yang bersumber data primer diperoleh dari jurnal yang kemudian dilakukan skrining jurnal yang diterbitkan selama 10 tahun terakhir sebagai kriteria. Literatur didapatkan secara online diberbagai jurnal internasional maupun nasional yang diakses dari situs Google Scholar dan ScienceDirect dengan kata kunci "Penerapan Metode Single Minute Exchange of Dies (SMED) di Industri" dan "Lean Manufacturing System (LMS)".

\section{Hasil dan Pembahasan}

\section{Lean Manufacturing System (LMS)}

Lean Manufacturing System (LMS) suatu sistem yang membantu industri untuk memenuhi tuntutan dari permintaan konsumen. Lean manufacturing berfokus dalam mengeliminasi pemborosan secara terstruktur pada proses produksi. Metode ini dapat diaplikasikan diberbagai rekayasa dan administratif dalam suatu industri. Konsep lean dengan istilah $3 \mathrm{M}$ yang berasal dari bahasa Jepang yaitu Muda (pemborosan), Mura (ketetapan), dan Muri (kelainan). ${ }^{9}$ Adapun delapan hal yang sering digunakan dalam analisis terjadinya pemborosan yaitu dapat disingkat DOWNTIME yaitu: 10

\section{- Defects (Kecacatan)}

Sering terjadi kesalahan dalam dokumen, masalah kualitas produk, atau kinerja pengiriman yang buruk.

- Overproduction (Produksi berlebihan)

Memproduksi terlalu banyak atau terlalu cepat, mengakibatkan aliran informasi atau barang yang buruk dan kelebihan persediaan.

- Waiting (Waktu tunggu)

Lama tidak aktifnya orang, informasi, atau barang, mengakibatkan aliran yang buruk dan waktu tunggu yang lama.

- Non-Utilised/ Underutilised Talent (Bakat yang tidak dimanfaatkan)

Industri gagal menggali atau memanfaatkan bakat, keterampilan atau pengetahuan khusus. Pemborosan ini terjadi ketika menajemen tidak responsive dan tidak menetapkan tugas dengan tepat atau tidak melatih dengan benar.

- Transportation (Transportasi)

Perpindahan orang, informasi, atau barang yang berlebihan yang mengakibatkan pemborosan waktu, tenaga, dan biaya.

- Inventory (Persediaan yang tidak perlu)

Penyimpanan dan keterlambatan informasi atau produk yang berlebihan, mengakibatkan biaya yang berlebihan dan layanan pelanggan yang buruk.

- Motion (Pekerjaan yang tidak perlu)

Organisasi tempat kerja yang buruk, mengakibatkan ergonomi yang buruk, misalnya pekerja yang melakukan pekerjaan kegiatan $A, B$, dan $C$, sehingga banyak pekerjaan yang dilakukan oleh pekerja tersebut sehingga menambah pekerjaan yang tidak diperlukan. 
- Excess Processing (Proses yang tidak perlu)

Melakukan proses kerja menggunakan seperangkat alat, prosedur, atau sistem yang salah, dapat memperhambat melakukan suatu aktivitas sehingga seringkali ketika pendekatan yang lebih sederhana dapat menghasilkan kinerja yang lebih efektif.

Metode yang sering digunakan dalam memangkas waktu pemborosan yaitu metode Single Minute Exchange of Dies (SMED) suatu metodologi inovasi berbasis proses di negara Jepang yang melibatkan pemisahan dari operasi aktivitas internal menjadi operasi aktivitas eksternal.

\section{Single-Minute Exchange of Dies (SMED)}

Single Minute Exchange of Dies (SMED) merupakan salah satu metode penyempurnaan dari LMS dalam mempercepat waktu yang dibutuhkan untuk melakukan waktu persiapan/pergantian dalam memproduksi satu jenis produk ke produk yang lainnya. Metode SMED memiliki beberapa istilah lain diantaranya yaitu Quick Change Over (QCO), Four Step Rapid Setup (4SRS), Setup Reduction, One Touch Setup (OTS), dan One Touch Exchange of Die (OTED) ${ }^{4}$ metode ini bertujuan untuk membuat strategi dalam mempercepat waktu persiapan/pergantian. ${ }^{11} 12$ Maksud dari "single minute" dalam Single Minute Exchange of Dies (SMED) bukan berarti dalam perubahan dan pergantian tipe hanya dalam satu menit tetapi waktu pergantian produk dapat dikurangi semaksimal mungkin sehingga mempercepat waktu oprasi yang dapat merubah seluruh proses. ${ }^{13}$

Waktu persiapan/pergantian sendiri diartikan sebagai lamanya waktu dibutuhkan saat proses produksi baik produk terakhir selesai maupun produk pertama. Waktu persiapan/pergantian merupakan waktu organizational seperti operator mempersiapkan peralatan, menghentikan mesin dan memanggil maintenance, melakukan pengaturan, uji coba sampai menghasilkan produk yang baik. ${ }^{4}$ Jenis aktivitas persiapan/pergantian yang umum terdapat di industri: ${ }^{14}$

Pertama, persiapan, pengecekan, peratalan dan alat sebelum melakukan persiapan/pergantian dimulai dan membersihkan, merapikan mesin.

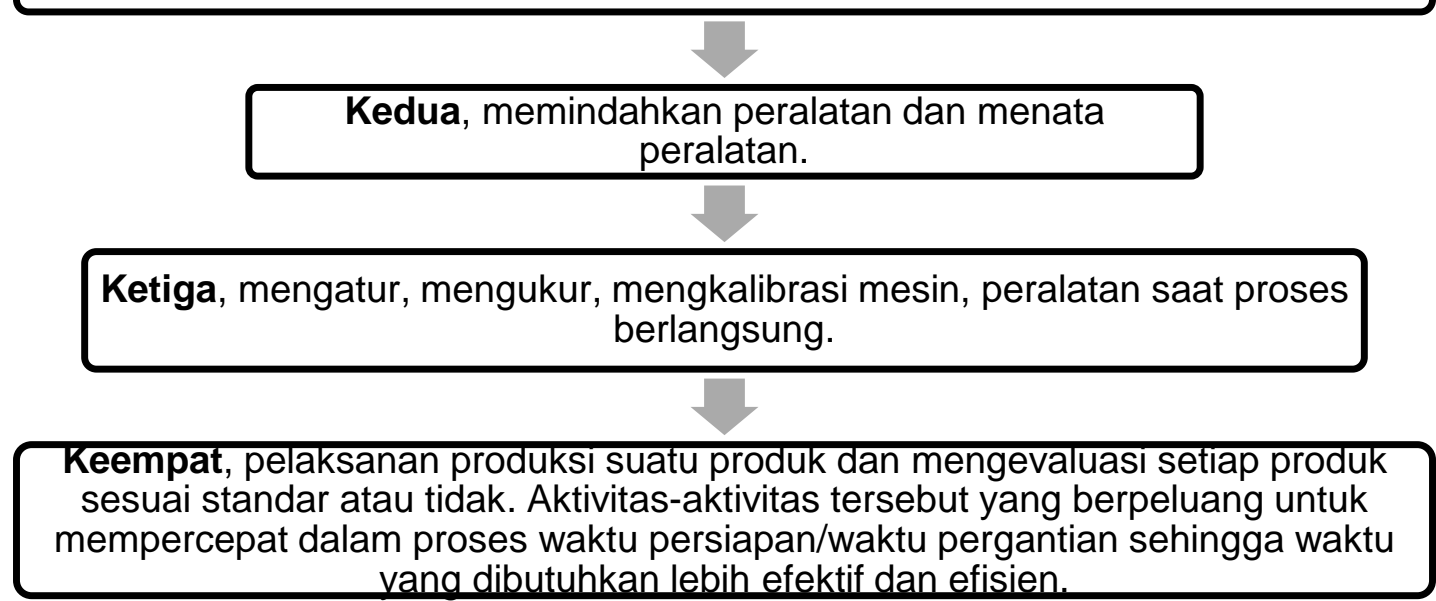

Gambar 1. Jenis aktivitas persiapan/pergantian yang umum terdapat di industri 
Alasan utama dalam pengurangan waktu persiapan/waktu pergantian yaitu

- Menyederhanaan prosedur persiapan/pergantian proses produksi, dimana operator dalam mengerjakan tugas yang lebih sederhana sehingga dapat meminimalkan kesalahan dalam pengoprasian dan mengurangi beban jam kerja dari operator, sehingga biaya yang dikeluarkan dengan waktu persiapan/pergantian dapat dikurangi.

- Menyederhanakan proses persiapan/pergantian sehingga dapat merespon cepat terhadap perubahan permintaan pasar, sehingga proses produksi harus dapat menghasilkan produk dengan kebutuhan yang ekonomis sesuai kebutuhan konsumen.

- Prosedur persiapan/pergantian yang sederdahan, tidak memerlukan operator yang ahli dalam mengerjakan proses persiapan/pergantian melainkan dapat dilakukan dengan operator yang sudah ada yaitu operator terlatih diindustri tersebut. Hal tersebut dapat dilakukan untuk memperkecil waktu berhenti operator. Sehingga tenaga ahli dipergunakan untuk kegiatan dalam pembuatan prosedur yang baru atau kegiatan persiapan/pergantian yang sulit. ${ }^{15}$

- Mengurangi waktu persiapan/pergantian dapat meningkatkan kapasitas yang tersedia dibandingkan harus memilih membeli kebutuhan yang baru. ${ }^{16}$

Adapun tahap implementasi metode SMED ini terdiri beberapa tahap sebagai berikut: ${ }^{17}$

\section{- Tahap Pendahuluan}

Melaksanakan beberapa pendekatan untuk mengetahui kondisi sistem produksi yang tersedia. Cara yang dilakukan dengan wawancara pekerja untuk mengetahui kondisi proses persiapan/pergantian, mendokumentasikan aktivitas operator mesin, proses ini tidak membedakan antara aktivitas internal dan aktivitas eksternal persiapan/pergantian, menganalisis proses dapat menggunakan pengukur watu, alat perekam dan kamera sebagai alat pendukung perhitungan.

- Tahap Pertama

Memisahkan aktivitas internal dan aktivitas eksternal persiapan/pergantian. Tahap ini menggunakan checlist untuk semua komponen dari setiap langkah proses produksi. Checlist ini digunakan untuk memeriksa apakah komponen tersebut sudah berada di tempat yang tepat. ${ }^{18}$

\section{- Tahap Kedua}

Mengubah aktivitas internal dan aktivitas eksternal persiapan/pergantian. Cara dalam mengubah aktivitas internal menjadi aktivitas eksternal dengan cara memeriksa kembali setiap proses apakah langkah yang salah sehingga diasumsikan sebagai aktivitas internal dan dapat diubah menjadi aktivitas eksternal.

\section{- Tahap Ketiga}

Menseleksi semua aspek proses, dengan memperbaiki aktivitas internal dengan perbaikan lanjutan untuk dapat meminimalkan aktivitas internal sehingga waktu berhenti mesin dapat diperkecil. 
Implementasi dalam metode SMED dapat dilakukan dengan mengonversi waktu persiapan/pergantian internal menjadi waktu persiapan/pergantian eksternal. Dimana waktu persiapan/pergantian internal merupakan kejadian saat mesin berhenti atau tidak beroperasi, sehingga kegiatan persiapan/pergantian tersebut dapat diubah menjadi waktu persiapan/pergantian eksternal dimana ketika mesin sedang beroperasi. ${ }^{19}$ Adapun tujuan kegiatan perubahan waktu persiapan/pergantian internal menjadi eksternal yaitu untuk meningkatkan produktivitas industri. Adapun keunggulan dari menggunakan metode SMED ini yaitu dapat menurunkan waktu persiapan/pergantian, mempersingkat manufacturing leadtime, memperkecil keterlambatan proses, mengurangi waktu tunggu, meniadakan oprasi proses yang tidak diperlukan, meningkatkan kapasitas industri, pengurangan ongkos produksi, pengiriman yang cepat, menurunkan biaya pengeluaran, sehingga meningkatkan kualitas dari produk yang dihasilkan. ${ }^{20,21}$

\section{Penerapan Metode SMED di Industri}

Penerapan dari metode SMED telah menjadi suatu langkah untuk menurunkan waktu persiapan/pergantian di berbagai industri. SMED merupakan metode yang efektif untuk menyediakan metode pergantian yang lebih baik yang menghasilkan pengurangan waktu dan tenaga secara keseluruhan dan juga membuktikan bahwa pengurangan pengaturan merupakan alat yang efektif yang dapat diterapkan untuk meningkatkan kemampuan organisasi manufaktur untuk meningkatkan kepuasan pelanggan melalui pemanfaatan sumber daya industri yang lebih baik. Langkah terpenting dalam penerapan SMED adalah membedakan antara kegiatan internal dan eksternal. ${ }^{22}$ Beberapa industri telah menerapkan metode SMED. Hasil yang diperoleh dari penelusuran literatur di berbagai jurnal mengenai implementasi dalam penggunaaan metode SMED di berbagai industri ditunjukkan pada Tabel 1.

Tabel 1. Penerapan Metode SMED di Industri

\begin{tabular}{|c|c|c|c|c|}
\hline Kegiatan & $\begin{array}{l}\text { Waktu } \\
\text { Sebelum } \\
\text { Perbaikan } \\
\text { (Menit) }\end{array}$ & $\begin{array}{l}\text { Waktu } \\
\text { Setelah } \\
\text { Perbaikan } \\
\text { (Menit) }\end{array}$ & $\begin{array}{l}\text { Persentase } \\
\qquad(\%)\end{array}$ & Referensi \\
\hline $\begin{array}{l}\text { Perbaikan waktu produksi dengan } \\
\text { mesin shrink. }\end{array}$ & 100,63 & 56,83 & 43,52 & (23) \\
\hline Pergantian cetakan mesin. & 782 & 413 & 47.1 & (24) \\
\hline Proses brand change rutin & 85.078 & 61.397 & 27,83 & \\
\hline terhadap mesin protos dan focke. & 179.105 & 103.444 & 42,24 & (4) \\
\hline Proses milling standard. & 673 & 283 & 58 & (25) \\
\hline $\begin{array}{l}\text { Proses produksi panel } \\
\text { telekomunikasi mesin punching. }\end{array}$ & 2.694 & 657,6 & 75,59 & (3) \\
\hline $\begin{array}{l}\text { Proses pengemasan primer produk } \\
\text { bulk krim menggunakan mesin } \\
\text { filling krim. }\end{array}$ & 61 & 49 & 19,67 & (26) \\
\hline Proses high-mix processing line. & 18940 & 14160 & 25 & (27) \\
\hline Proses pencucian drum plastik. & 39,73 & 32,74 & 17,59 & (28) \\
\hline Proses mesin feeder AID 1100. & 30 & 16,70 & 52,9 & (29) \\
\hline
\end{tabular}


Proses penginputan mesin secara manual dan digital.

Lean manufacturing in carriage building press shop.

Printing work station.

Bearing ring grinding machine.

Reducing setup time activity in drying room.

Profiles extrusion production

system.

Mesin

SK40 A VBM

STANKO

TITAN 2700

$66 \mathrm{VTL}$.

Otomotif system.

Mesin milling dan VMC.

Roll forming

Bender CNC 18 tdrel.

Pergantian moulding.

Otomotif System.

Proses mesin flexo.

Air conditioner business unit.

Mesin Cetak

WEB

TSK.

Service mesin.

Bench auto tempo print

Bench manual checker

Bench coil winding and testing.

Proses changelenght

Proses convertion

Proses convertion kombiner.

Mesin power brand.

Prakitan part airlayer tempest.

Waktu kegiatan dandori.

\begin{tabular}{|c|c|c|}
\hline 24.065 & 14.416 & 58,3 \\
\hline 98 & 60 & 38,77 \\
\hline 18:29" & 14: $37 "$ & 46 \\
\hline 195 & 114 & 41,53 \\
\hline 159,67 & 108,55 & 32,02 \\
\hline 8,98 & 7,59 & 15,47 \\
\hline 150 & 85 & 43 \\
\hline 150 & 90 & 40 \\
\hline 55 & 45 & 18,18 \\
\hline 200 & 90 & 55 \\
\hline 1019 & 628 & 38,4 \\
\hline 5,65 & 4,26 & 24,60 \\
\hline 37.242 & 7.517 & 79,81 \\
\hline 28.767 & 4.217 & 85,34 \\
\hline 46,87 & 43,80 & 28,8 \\
\hline 8 & 6,41 & 19,87 \\
\hline 31861,968 & 39075,648 & 52,26 \\
\hline 2036,15 & 931,15 & 54,27 \\
\hline
\end{tabular}


Tahapan pendahuluan dan tahap pertama yang dilakukan metode SMED yaitu melakukan observasi lapangan, kemudian melakukan identifikasi pemborosan proses produksi, dilanjutkan dengan evaluasi dari waktu persiapan/pergantian tersebut. Kemudian dilakukan identifikasi terhadap faktor-faktor penyebab terjadinya pemborosan. Permasalahan pemborosan dalam suatu industri dapat dianalisis dengan faktor penyebab permasalahan dengan mencari $5 \mathrm{~W}+1 \mathrm{H}$ lalu ditelusuri untuk mendapatkan solusinya (brainstorming). ${ }^{45}$ Hasil penelusuran literatur diketahui bahwa faktor penyebab permasalahan terjadinya waktu henti mesin dan waktu waktu persiapan/pergantian dapat di identifikasi oleh beberapa ilustrasi dengan diagram fishbone, Plan-Do-Check-Ad (PDCA) dan FMEA suatu alat pengambilan keputusan yang dapat memprioritaskan sehingga mengeliminasi peringkat kegagalan. ${ }^{26,22,46}$ Tahap yang kedua yaitu identifikasi aktivitas persiapan/pergantian dengan melihat atau memisahkan antara aktivitas internal dan aktivitas eksternal. Aktivitas internal merupakan suatu kegiatan persiapan/pergantian yang dikerjakan pada saat mesin produksi dalam keadaan mati. Sedangkan untuk aktivitas eksternal merupakan persiapan/pergantian yang dikerjakan saat mesin produksi masih melakukan pengoprasian. Lalu dari pemisahan tersebut dilihat perubahan operasi persiapan/pergantian internal dan eksternal. Tahap ini dapat menganalisa secara terperinci dari setiap elemen-elemen oprasi. Beberapa penelitian untuk mencatat waktu dari aktiviras waktu persiapan/pergantian pada mesin dilakukan menggunakan pengukur watu, alat perekam dan kamera. ${ }^{47}$ Salah satu hal penting dalam metode SMED yaitu mempercepat mengkonversi wantu aktivitas internal menjadi aktivitas eksternal diutamakan dan menghilangkan proses pemberhentian yang dilakukan oleh operator saat melakukan produksi sehingga perubahan tersebut dapat diimplementasikan dengan melihat perubahan sekitar 1 bulan. ${ }^{48}$ Perhitungan waktu persiapan/pergantian yang telah diterapkan menggunakan metode SMED ini dapat dihitung dengan rumus:

$$
\text { Improvement waktu }=\frac{\text { Waktu Internal-Waktu Eksternal }}{\text { Waktu Internal }} \times 100 \%
$$

Perhitungan aktivitas internal dihitung saat mesin dalam keadaan waktu henti, tetapi untuk aktivitas eksternal tidak dihitung waktu henti dikarenakan aktivitas eksternal ini merupakan suatu aktivitas mesin dalam keadaan beroprasi. Analisis masalah dan perbandingan perubahan akhir dan awal, maka dapat diperoleh kesimpulan dan saran yang digunakan sebagai rekomendasi untuk perubahan. ${ }^{49}$ Berdasarkan sumber literatur diatas dari data hasil perbaikan waktu persiapan/pergantian yang diperoleh sangat signifikan dengan rata-rata penurunan persentase sebesar 39,97\%. Mengatur aktivitas secara sistematis dalam pengaturan waktu dengan SMED membantu dalam meningkatkan aktivitas waktu persiapan/pergantian dan membantu dalam implementasi alur baru aktivitas waktu persiapan/pergantian. Aktivitas waktu persiapan/pergantian yang lebih sederhana dapat mengurangi terjadinya kecelakan dalam kerja. Jika analisis delapan pemborosan yang dibuat seminimal mungkin dapat mengurangi kesalahan di area kerja sehingga membuat proses produksi menjadi lebih optimal. Dalam hal perkembangan di masa depan, pembentukan satu atau lebih tim SMED adalah suatu keharusan untuk perbaikan dalam meningkatkan kualitas industri.50 Peralatan persiapan/pergantian yang telah memenuhi standar memudahkan dalam pelacakan. ${ }^{51}$ Ide utama dari sistem ini adalah untuk menyediakan metode dan menggunakan solusi kreatif dan inovatif untuk perbaikan berkelanjutan. ${ }^{52}$ 


\section{Kesimpulan}

Metode SMED digunakan untuk mengoptimalkan proses pergantian dan untuk menghilangkan dampak negatif dari perubahan program produksi yang sering terjadi seperti pengaturan dan penyesuaian mesin. Metode SMED ini merupakan metode yang cukup efisien dan efektif dalam mereduksi waktu persiapan/pergantian yang tidak seharusnya. Hal ini dapat dilihat dari beberapa literatur yang telah menggunakan metode SMED dalam implementasi proses produksi dimana perbandingan waktu sebelum perbaikan dan setelah perbaikan dengan metode SMED memiliki penurunan yang cukup signifikan sehingga hasil yang telah diperoleh ini dapat diperhatikan oleh industri-industri industri terutama industri farmasi dengan demikian metode tersebut dapat diterapkan dalam pelaksanaan proses produksi, dan industri dapat menghasilkan produk yang lebih efisien yang dapat memuaskan kebutuhan konsumen.

\section{Daftar Pustaka}

1. Supriyanto. 2014. Otimasi Waktu/Proses Produksi Di PT. Sumiden Sintered Component Indonesia dengan Teknik Analisa Network/Pert Dan Metode SMED. Jurnal PASTI. 2014; 8(3): 362-398.

2. Nurrizky, M. F., M. A. Septiana, J. Machmudin, dan M. Syafii. 2021. Peningkatan Efisiensi Mesin CNC Turning Menggunakan Metode Singgle Minutes Exchenge of Dies di PT. X. Jurnal IImiah Teknologi Informasi Terapan. 7(2): 94-100.

3. Mulyana, A. dan S. Hasibuan. 2017. Implementasi Single Minute Exchange of Dies (Smed) untuk Optimasi Waktu Changeover Model Pada Produksi Panel Telekomunikasi. Sinergi. 21(2): 107-114.

4. Rahayu, A.S.W. 2020. Implementasi Single Minute Exchange of Dies (Smed) Untuk Perbaikan Proses Brand Changeover Mesin Focke Dan Protos. Jurnal Industry Xplore. 5(1):1-9

5. Supriyanto. 2014. Otimasi Waktu/Proses Produksi Di PT. Sumiden Sintered Component Indonesia dengan Teknik Analisa Network/Pert Dan Metode SMED. Jurnal PASTI. 2014; 8(3): 362-398.

6. Resurreccion, P.F. 2012. Performance Management and Compensation as Drivers of Organization Competitiveness: The Philippine Perspective. International Journal of Business and Social Science. 2012;3(21): 20-30.

7. Nurrizky, M. F., M. A. Septiana, J. Machmudin, dan M. Syafii. 2021. Peningkatan Efisiensi Mesin CNC Turning Menggunakan Metode Singgle Minutes Exchenge of Dies di PT. X. Jurnal IImiah Teknologi Informasi Terapan. 7(2): 94-100.

8. Heriansyah, E. dan Z. F. Ikatrinasari. 2017. Peningkatan Kinerja Operator Pada Mesin Fukui 600 Ton Menggunakan Metode Exchange ff Dies (SMED). Jurnal PASTI. 2017;11(2): 142-148.

9. Purnomo, E., A. R. Dwicahyani, dan Z. Lailahulhaq. 2021. Analisa dan Perbaikan Waktu Set-up Pergantian Cetakan dengan Metode Single-Minute Exchange of Dies (SMED) (Studi Kasus: PT. XYZ). Seminar Nasional Teknologi Industri Berkelanjutan I (SENASTITAN I). 2021 Maret 6; Surabaya, Indonesia. Indonesia: Institut Teknologi Adhi Tama Surabaya; 2021. 
10. Jaffar, A., S. Kasolang, Z. A. Ghaffar, N. S. Mohammad, and M. K. F. Mohammad. 2015. Management of Seven Pemborosans: A Case Study in an Automotive Vendor. Jurnal Teknologi. 76(6): 19-23.

11. Dave, Y. dan N. Sohani. 2012. Single Minute Exchange of Dies: Literature Review. International Journal of Lean Thinking. 2012; 3(2): 28-37.

12. Joshi, R. R. dan G.R. Naik. 2012. Application of SMED Methodology- A Case Study in Small Scale Industry. International Journal of Scientific and Research Publications. 2012;2(8): 1-4.

13. Rivai, Y., A. M. Fauzi, dan M. S. Rusli. Overall Ewuipment Effectiveness dalam Peningkatan Kinerja Produksi Ban PT Goodyear Indonesia. Jurnal Aplikasi Bisnis dan Manajemen. 2(2): 148-160.

14. Giona, S. I. dan J. Raharjo. 2017. Usulan Improvement Moulding Plan di PT. X. Jurnal Titra. 5(1); 101-106.

15. Supriyanto. 2014. Otimasi Waktu/Proses Produksi Di PT. Sumiden Sintered Component Indonesia dengan Teknik Analisa Network/Pert Dan Metode SMED. Jurnal PASTI. 2014; 8(3): 362-398.

16. Raikar, N. A. 2015. Reduction in Setup Time by SMED Methodology: A Case Study. International Journal of Latest Trends in Engineering and Technology (IJLTET). 5(4): 56-60.

17. Suhardi, B. dan D. Satwikaningrum. 2015. Perbaikan Waktu Set Up Dengan Menggunakan Metode SMED. Seminar Nasional IENACO - 2015. ISSN 2337-4349.

18. Maldini, G. dan N. Yuselin. 2019. Pengurangan Waktu Proses Penggantian Dies Di Mesin Press 75 Ton Nouguchi untuk Meningkatkan Kapasitas Produksi Di PT. Laksana Tekhnik Makmur. TECHNOLOGIC. 10(1): 1-11.

19. Roswandi, I. 2019. Lean Manufacturing Konsep untuk Meningkatkan Efektivitas Mesin Moulding Menggunakan Pendekatan Smed Di Pt Xyz. Jurnal Penelitian dan Aplikasi Sistem \& Teknik Industri (PASTI). 2019; 13(1): 17-25.

20. Saputra, R., H. Arianto, dan L. Irianti. 2016. USULAN MEMINIMASI WAKTU SETUP DENGAN MENGUNAKAN METODE SINGLE MINUTE EXCHANGE DIE (SMED) DI INDUSTRI X. Jurnal Teknik Industri Itenas. 2016; 2(4): 206- 218.

21. Rasjidin, R. dan H. Prasetyo. 2015. Usulan Pengurangan Setup Time untuk Pergantian Dies Pressing Blanking dan Bending pada Lini Produksi Plate Center KVBA dengan Metode SMED di PT. Dwiutama Intiterang. Jurnal Inovisi. 11(2): 8397.

22. Sivasankar, M., N. Dhandapani, Manojkumar, Karthick, Raja, dan Yuvaraj. 2011. Experimental verification of Single Minute Exchange of Dies (SMED). Recent Research in Science and Technology. 2011;3(3): 92-97.

23. Wibowo., A.D.W. dan Lukmandono. 2021. Implementasi Metode Single Minute Exchange of Dies (SMED) dan Maynard Operation Sequence Technique (MOST) untuk Perbaikan Waktu Proses Produksi (Studi Kasus Departemen ProduksiWrapping di PT. X Surabaya). Seminar Nasional Teknologi Industri Berkelanjutan I (SENASTITAN I). ISSN: 2775-5630.

24. Lukmandono., R. Soesilo., M. Basuki., dan M. J Hidayat. 2018. Minimasi Waktu Penggantian Cetakan Dengan Pendekatan Lean Manufacture \& Single Minute Exchange Of Dies (SMED). Simposium Nasional RAPI XVII; 2018, Indonesia: UMS. 
25. Arifin, Djauhar. 2013. Analisis Perbaikan Waktu Setup dengan Menggunakan Metode SMED untuk Meningkatkan Produktivitas PT. Trimitra Chitra Hasta. Jurnal Kalibrasi. 8:1-14.

26. Arief, F. N. dan Z. F. Ikatrinasari. 2018. Perbaikan Waktu Setup Dengan Menggunakan Metode Smed Pada Mesin Filling Krim. Jurnal IImiah Teknik Industri. 6(1): $1-8$.

27. Filla, J. 2016. The Single Minute Exchange of Die Methodology in a High-Mix Processing Line. Journal of Competitiveness. 8(2): $59-69$.

28. Huduni, R. dan B. Purwanggorp. 2018. Perbaikan Waktu Pada Pencucian Drum Plastik dengan Metode Single Minute Exchange of Die (SMED) (Studi Kasus: Washing Area Departemen Operasi PT. Bayer Indonesia). Industrial Engineering Online Journal. 7(4): 1-5.

29. Arvianto, A. dan R. Arista. 2011. Usulan Perbaikan Operation Point Sheet Pada Mesin Feeder Aida 1100 Pt. Xxx Dengan Menggunakan Metode Smed. J@TI Undip. 6(2):125-136.

30. Adanna, I. W. and A. Shantharam. 2013. Improvement of Setup Time and Production Output with the use of Single Minute Exchange of Die Principles (SMED). International Journal of Engineering Research. 2(4): 274-277.

31. Sivakumar, M., T. Balasubramani, and M. C. Satny. 2015. Lean Manufacturing in Carriage Building Press Shop using by SMED and VSM tools. International Journal of Innovations in Engineering and Technology (IJIET). 5(3):235-241.

32. Indrawati, Sri., M. Endah Pratiwi, Sunaryo, and A. Azzam. 2018. The effectiveness of single-minute exchange of dies for lean changeover process in printing industry. MATEC Web of Conferences (154).

33. Pawar,G., N.S. Sirdeshpande, A.B. Atram, and P.R. Patil. 2014. Reduction in setup change time of a machine in a bearing manufacturing plant using SMED and ECRS. international Journal of Engineering Research. 3(5): 321-323.

34. Syafei., M. Y. and T. Lokadipati. 2018. Improving Work System by Reducing Setup Time Activity in Drying Room in Pharmaceutical Industry with Single Minutes Exchange Die (SMED). Journal of Industrial Engineering, Scientific Journal on Research and Application of Industrial System. 3(1): 50-58

35. Assaf, R. and T. Haddad. 2017. An Application of Single Minute Exchange of Die Approach in an Aluminum Profiles Extrusion Production System: Case Study. International Journal of Scientific Research and Innovative Technology. 4(7): 14-22.

36. Mali, Y. R dan KH. Inamdar. 2012. Changeover Time Reduction Using SMED Technique of Lean Manufacturing. International Journal of Engineering Research and Applications (IJERA). 2(3): 2441-2445.

37. Wisnubroto, T.J. dan A. Arvianto. 2015. Upaya Peningkatan Produktivitas dengan Menggunakan Metode Single Minute Exchange Of Die (SMED) (Studi Kasus : PT. Purinusa Eka Persada). Industrial Engineering Online Journal. 2015; 4(1): 1-5.

38. Fathia, R.N., S. Batubara, dan D.M. Safitri. 2016. Usulan Pengurangan Waktu Setup Menggunakan Metode SMED serta Pengurangan Waktu Proses Produksi Dan Perakitan Menggunakan Metode Most di PT. Panasonic Manufacturing Indonesia. Jurnal Teknik Industri. 2016; 6(2): 187-196. 
39. Bimantoro, I., W. Fatmawati, dan A. Syakhroni. 2020. Usulan Single Minute Exchange Of Die (SMED) Dan Konsep 5s untuk Mereduksi Waktu Setup Pada Mesin Web Dan Tsk (Studi Kasus : CV. Aneka Ilmu Semarang). Prosiding KONFERENSI ILMIAH MAHASISWA UNISSULA (KIMU) 3. 2020 Oktober 5; Semarang, Indonesia. Indonesia: Universitas Islam Sultan Agung; 2020.

40. Anfasah, R. 2020. Perbaikan Waktu Service Mobil Avanza dengan Menggunakan Metode Single Minute Exchange of Die di PT Astrido Jaya Mobilindo Jakarta. Scientifict Journal of Industrial Engineering. 1(2): 74-77.

41. Sudargo, K. W. dan Felecia. 2015. Penurunan Waktu Changeover dengan Metode SMED di PT.Schneider Electric Manufacturing Batam-Plant Electro Mechanic. Jurnal Titra. 3(2): 35-40.

42. Rio, G., Soegihardjo, dan Oegik. 2017. Pembuatan Sistem Penghitungan Overall Equipment Effectiveness (OEE), Pendataan Downtime dan Penerapan Quick Changeover untuk Meningkatkan Produktifitas di PT. Z. Mechanova. 6: 1-6.

43. Lowrenzo, D. S. dan A. Komariah. 2020. Pengaruh Perbaikan Waktu Setup terhadap Produktivitas Perakitan Air Layer Tempest (Studi Kasus di PT. X). JAPTI: Jurnal Aplikasi Imu Teknik Industri. 1(1): 1-7.

44. Sudarmaji, H. dan R. Sidiq. 2019. Menurunkan Waktu Proses Dandori dengan Metode Single Minute Exchange of Die Di Area Produksi PT Aski. TEKNOLOGIC. 10(1): 1-10.

45. Nuryono, A. 2018. Analisis Efektifitas Kinerja Excavator pada Aktivitas OB Removal Penambangan Batubara Menggunakan Metode OEE (Studi Kasus: PT. RML Embalut - Kalimantan Timur). Journal Industrial Manufacturing. 3(2): 78-88.

46. Aized, T., M. Ahmad, M.H. Jamal, A. Mohmood, S.U.U. Rehman, and J. S. Srai. 2020. Automotive leaf spring design and manufacturing process improvement using failure mode and effects analysis (FMEA). International Journal of Engineering Business Management. 2020; 12: 1-13.

47. Ruhul, R. J. 2012. Reduction in Setup Time by SMED a Literature Review. Journal of Modern Engineering Research. 2(2): 442-444.

48. Prasetyowati, N. P, A. Rahman, dan C. F. M. Tantrika. 2013. Perbaikan Waktu SetUp Dengan Pendekatan Single Minute Exchange of Dies (Smed) untuk Mengurangi Unnecessary Motion Pemborosan (Studi Kasus : PT. Berlina Tbk. Pandaan). Jurnal Rekayasa dan Manajemen Sistem Industri. 1(1): 1-10.

49. Tanzil, R.N., D.D. Damayanti, dan P.P. Saryadhini. 2015. Usulan Perbaikan Waktu Setup Dalam Meminimasi Keterlambatan Penyelesaian Order Pada Komponen Isolating Cock dengan Metode SMED Di PT Pindad (Persero). e-Proceeding of Engineering. 2015; 2(2): 3982.

50. Wani, M. dan R. Pant. 2017. Implementation of Single Minute Exchange of Die in Motor Manufacturing Unit. International Research Journal of Engineering and Technology (IRJET). 2017;4(11): 1300-1310. 
51. Claudia, J. dan Felecia. 2017. Pengurangan Downtime Mesin Offset di PT X. Jurnal Titra. 5(2): 131-136.

52. Hashemzadeh, G. R., M. Khoshtarkib, and S. Hajizadeh. 2014. Identification and Weighting Factors Influencing the Establishment of a Single Minute Exchange of Dies In Plastic Injection Industry using VIKOR and Shannon Entropy. Management Science Letters .2014; 4: 977-984. 